\title{
STUDI KELAYAKAN FINANSIAL USAHA PETAMBAK UDANG VANAME (Litopenaeus vannamei) SEMI INTENSIF
}

\author{
F. Lutfiana ${ }^{1 \mathrm{a}}$, A. Arsyad ${ }^{1}$ dan A Yoesdiarti ${ }^{1}$ \\ ${ }^{1}$ Jurusan Agribisnis, Fakultas Pertanian Universitas Djuanda Bogor \\ Jalan Tol Ciawi No. 1 Kotak Pos 35 Bogor 16720 \\ a'Korespondensi: Fajar Lutfiana, Email : fajar.lutfiana@unida.ac.id
}

\begin{abstract}
ABSTRAK
Penelitian ini bertujuan untuk mengetahui keragaan, kelayakan dan sensitivitas usaha petambak udang vaname semi intensif. Metode penelitian menggunakan purposive dan simple random sampling. Jumlah responden yang digunakan yaitu sebanyak 34 orang. Data dianalisis menggunakan analisis deskriptif melalui wawancara dan kuantitatif melalui analisis kelayakan finansial menggunakan kriteria penilaian investasi. Data diolah menggunakan bantuan Microsoft Excel 2010. Hasil penelitian menunjukkan bahwa keragaan usaha petambak udang vaname semi intensif di Desa Bumi Dipasena Agung adalah : Sumber modal terbesar yang digunakan adalah sendiri dan pinjaman dengan persentase sebesar $68 \%$, padat tebar terbesar yaitu $11-20$ ekor/m2 dengan persentase sebesar $71 \%$ atau rata-rata yaitu 19 ekor/m2 , usia tebar benur yaitu terbesar adalah post larva (PL) 10 dengan persentase sebesar $32 \%$ atau rata-rata yaitu PL 10, Lama pembudidayaan yaitu selama 75 hari, rantai pemasaran yaitu dari petembak kepada tengkulak, kelembagaan petambak yang diikuti adalah Perhimpunan Petambak Pengusaha Udang Wilayah (P3UW) Lampung, penentuan harga adalah ditentukan oleh tengkulak, proses pembayaran terbesar adalah tidak langsung dengan persentase sebesar $91 \%$. Hasil analisis kelayak finansial menunjukkan bahwa usaha ini layak dengan nilai Net Present Value (NPV) sebesar Rp.131.035.409 yang berarti layak yaitu lebih dari 0, Internal Rate of Return (IRR) sebesar 36,5\% yang berarti lebih besar dari bunga pinjaman yaitu 9\%. Profiitability Index (PI) sebesar 1,98 yang berarti setiap Rp.1 biaya yang dikeluarkan maka akan diperoleh keuntungan sebesar Rp.0,98, dan Discounted Payback Period (PP) selama 4 Tahun 3 Bulan yaitu layak sebab lebih kecil dari umur ekonomis usaha yaitu 7 Tahun dan berarti modal akan kembali setelah usaha berjalan selama 4 Tahun 3 Bulan. Analisis sensitivitas menunjukkan bahwa maksimum penurunan jumlah produksi dan harga jual sebesar 22,37\% serta maksimum kenaikan harga pakan sebesar 107,24\%, dan benur sebesar $280,99 \%$.
\end{abstract}

Kata Kunci :, NPV, IRR, PI, DPP, Sensitivitas 



\section{PENDAHULUAN}

Udang merupakan salah satu komoditas utama dalam program industrialisasi perikanan budidaya dan merupakan andalan ekspor produk perikanan. Produksi perikanan budidaya komoditas udang selama tahun 2010-2014 yang memiliki kecenderungan terus naik (lihat lampiran 3). Produksi udang secara umum terus menerus meningkat, kenaikan rata-rata udang selama tahun 2010 sampai dengan 2014 adalah 13,83 persen pertahun (DJPB, 2015).

Salah satu jenis udang yang banyak diminati oleh petambak di Indonesia adalah udang vaname. Udang vaname memiliki sejumlah keunggulan salah satunya yaitu lebih tahan terhadap penyakit. Udang vaname merupakan udang introduksi, kehadiran udang vaname diharapkan dapat menambah pilihan bagi petambak serta menopang kebangkitan udang di Indonesia.

Petambak di Indonesia pada umumnya menerapkan tiga teknologi dalam budidaya Udang Vaname yaitu tradisional, semi intensif, dan intensif. Semakin tinggi teknologi yang diterapkan maka semakin besar pula padat tebar pemeliharaannya. Salah satu teknologi yang diterapkan para petambak saat ini adalah semi intensif. Kelebihan dari sistem semi intensif adalah bisa memanfaatkan pakan alami dan juga membutuhkan biaya produksi yang lebih kecil dibandingkan sistem intensif.

Provinsi Lampung merupakan salah satu produsen penghasil Udang Vaname di Indonesia. Luas lahan potensial untuk budidaya air payau, baik untuk pembesaran udang/ikan atau pembenihan luasnya mencapai $61.200 \mathrm{Ha}$ (Bank Indonesia, 2015). Lampung merupakan produsen penghasil Udang Vaname terbesar di Indonesia yaitu mencapai 72.051 ton pada tahun 2013 (DJPB, 2013). Salah satu kabupaten penghasil Udang Vaname di Lampung adalah Tulang Bawang atau lebih dikenal sebagai kota udang. Kecamatan Rawajitu Timur merupakan salah satu penyumbang hasil budidaya udang vaname di Kabupaten Tulang Bawang. Pekerjaan utama sebagian besar penduduk menurut lapangan usaha di kecamatan ini adalah petambak udang. Bumi Dipasena Agung merupakan salah satu desa yang ada di Kecamatan Rawajitu Timur. Jumlah kepala keluarga sebanyak 613 pada tahun 2016 (BPS Kabupaten Tulang Bawang, 2017).

Desa Bumi Dipasena Agung merupakan salah satu desa bekas kawasan minapolitan antara petambak plasma yang bermitra dengan perusahaan swasta. Saat ini penggunaan lahan tambak di Desa Bumi Dipasena Agung yaitu sebanyak 1.920 petak $\left(2.000 \mathrm{~m}^{2}\right.$ per petak) dari 2.400 petak yang ada atau $80 \%$ penggunaannya.

Besarnya wilayah pertambakan di Desa Bumi Dipasena Agung dapat menjadi peluang bagi para pihak yang ingin berinvestasi atau bertambak, namun tingginya biaya usaha menghambat petambak untuk memaksimalkan teknologi budidaya yang ada, oleh sebab itu teknologi semi intensif bisa menjadi solusi bagi permasalahan yang dihadapi petambak.

Usaha tambak Udang Vaname semi intensif di Desa Bumi Dipasena Agung penting untuk dilakukan studi kelayakan yaitu pada aspek finansial. Sebagai penunjang, perlu diketahui informasi mengenai aspek pasar, teknis, sosial ekonomi, dan dampak lingkungan. Selain itu perubahan-perubahan terhadap biaya dan pendapatan juga perlu diperhatikan dan ditinjau kembali supaya dapat memenuhi tingkat menimum diterimanya suatu proyek.

Penelitian ini bertujuan untuk mengetahui keragaan usaha petambak udang vaname semi intensif, menganalisis kelayakan finansial usaha petambak udang vaname semi intensif dan menganalisis sensitivitas kelayakan finansial usaha petambak udang vaname semi intensif di Desa Bumi Dipasena Agung terhadap perubahan biaya dan penerimaan 


\section{BAHAN DAN METODE PENELIAN}

\section{Lokasi dan Waktu}

Penelitian ini dilaksanakan di Desa Bumi Dipasena Agung, Kecamatan Rawajitu Timur, Kabupaten Tulang Bawang, Provinsi Lampung. Pemilihan lokasi ini ditentukan secara sengaja (purposive) dengan pertimbangan bahwa desa ini merupakan salah satu desa penghasil Udang Vaname yang menerapkan budidaya sistem semi intensif di Kecamatan Rawa Jitu Timur. Pengumpulan data di lokasi penelitian dilaksanakan pada tanggal 15 sampai dengan 31 Januari 2019.

\section{Sumber dan Jenis Data}

Data yang digunakan yaitu data primer melalui observasi lapang dan wawancara kepada petambak. Wawancara terhadap petambak dilakukan dengan menggunakan bantuan kuisioner. Sedangkan data sekunder diperoleh dari litelatur pada instansi-instansi terkait seperti buku, jurnal, skripsi, BPS, DJPB, serta instansi lainnya.

\section{Metode Penentuan Responden}

Penentuan responden dalam penelitian ini dilakukan melalui metode purposive sampling yaitu teknik pemilihan responden yang dilakukan secara sengaja sesuai dengan kriteria untuk dijadikan sampel. Jumlah petambak yang ada di lokasi penelitian adalah kurang lebih sebanyak 600 orang. Jumlah responden yang digunakan dalam penelitian ini adalah sebanyak 34 orang yaitu para petambak udang vaname semi intensif yang memenuhi kriteria penilaian sebagai berikut :

1. Pengalaman bertambak lebih dari 5 tahun.

2. Bertambak sebagai pekerjaan utama.

3. Produksi relatif konstan (setiap tahun berproduksi minimal 2 kali).

4. Tambak yang digunakan yaitu 2 petak $\left(2.000 \mathrm{~m}^{2}\right.$ per petak).

Jumlah petambak yang memenuhi kriteria penelitian adalah sebanyak 95 orang. Pemilihan selanjutnya adalah menggunakan metode simple random sampling yaitu teknik pengambilan sampel dari anggota populasi dengan cara acak melalui undian sebanyak 34 responden.

Jumlah responden yang digunakan pada aspek kelayakan non finansial adalah sebanyak 45 orang yaitu petambak 34 orang, unsur desa 2 orang, tengkulak 3 orang, suplier penyedia input 3 orang, dan badan pengurus infra blok 4 dan 5 P3UW Lampung 3 orang

\section{Metode Pengelolaan dan Analisis Data}

Analisis data yang digunakan dalam penelitian ini dilakukan secara kualitatif dan kuantitatif berdasarkan data primer dan sekunder yang diperoleh dari hasil penelitian. Analisis kualitatif diuraikan secara deskriptif untuk mengetahui gambaran umum, keragaan usaha, serta aspek pasar, teknis, sosial ekonomi dan dampak lingkungan. Sedangkan analisis kuantitatif dilakukan untuk mengetahui kelayakan finansial usaha petambak Udang Vaname dengan perhitungan data yang telah diperoleh. Data primer yang telah diperoleh dari hasil wawancara dengan responden diolah menggunakan program Microsoft Excel 2010.

\section{Analisis Kelayakan Finansial}

Kriteria kelayakan finansial yang digunakan dalam penelitian ini diuraikan sebagai berikut :

a. $\quad$ Net Present Value (NPV)

Rumus menghitung NPV adalah (Kasmir dan Jakfar, 2015) :

$\mathrm{NPV}=\frac{\text { Kas bersih } 1}{(1+\mathrm{r})}+\frac{\text { Kas bersih } 2}{(1+\mathrm{r})^{2}}+\ldots$

$+\frac{\text { Kas bersih N }}{(1+r)^{n}}-$ Investasi

Kriteria penilaian :

$>$ NPV positif, maka investasi diterima; dan sebaliknya

b. Internal Rate of Return (IRR)

Rumus menghitung IRR adalah (Kasmir dan Jakfar, 2015) : 
Keterangan :

$$
\mathrm{IRR}=\mathrm{i}_{1}+\frac{\mathrm{NPV}_{1}}{\mathrm{NPV}_{1}-\mathrm{NPV}_{2}} \times\left(\mathrm{i}_{2}-\mathrm{i}_{1}\right)
$$

$\mathrm{NPV}_{1}=$ Net Present Value 1

$\mathrm{NPV}_{2}=$ Net Present Value 2

$\mathrm{i}_{2}=$ Tingkat bunga 1 (tingkat

discount rate yang menghasilkan $\mathrm{NPV}_{1}$ )

$\mathrm{i}_{1}=$ Tingkat bunga 2 (tingkat

discount rate yang menghasilkan $\mathrm{NPV}_{2}$ )

Kriteria penilaian :

$>\quad$ Jika IRR lebih besar (>) dari bunga pinjaman maka diterima, dan sebaliknya

b. Profitability Index (PI)

Rumus menghitung PI adalah (Kasmir dan Jakfar, 2015) :

$$
\text { PI }=\frac{\sum \text { PV Kas Bersih }}{\sum \text { PV Investasi }} \times 100 \%
$$

Kriteria penilaian :

$>$ Apabila PI lebih besar (>) dari 1 maka diterima, dan sebaliknya

d. Discounted Payback Period (DPP) Rumus menghitung DPP adalah (Khrisna $d k k, 2013)$ :

$$
\mathrm{DPP}=\mathrm{n}+\frac{\mathrm{a}-\mathrm{b}}{\mathrm{c}} \times 12 \text { bulan }
$$

Keterangan :

$\mathrm{n}$ : tahun terakhir dimana arus kas belum bisa menutupi initial invesment

a : jumlah initial invesment (total investasi)

b : jumlah komulatif arus kas bersih yang telah dikalikan diskon faktor tahun ke-n

c : jumlah arus kas bersih yang telah dikalikan df tahun ke-n+1

Kriteria penilaian :

$>\quad$ PP sekarang lebih kecil dari umur investasi maka layak, dan sebaliknya.

\section{Analisis Sensitifitas}

Meneliti kembali suatu analisa untuk dapat melihat pengaruh-pengaruh yang akan terjadi akibat keadaan yang berubahubah disebut sebagai analisis sensitifitas (sensitivity analysis). Pada bidang pertanian, proyek-proyek sensitif berubah- ubah akibat empat masalah utama yaitu ; harga, keterlambatan pelaksanaan, kenaikan biaya, dan hasil. Suatu variasi pada analisis sensitivitas adalah switching value (Gittinger, 2008).

Beberapa variabel yang digunakan dalam analisis sensitivitas pada penelitian ini adalah :

1. Penurunan jumlah produksi

2. Penurunan harga jual

3. Kenaikan harga pakan

4. Kenaikan harga benur

\section{Asumsi-Asumsi yang Digunakan}

1. Umur ekonomis proyek adalah 7 tahun, berdasarkan umur ekonomis mesin-mesin produksi.

2. Harga yang digunakan diasumsikan konstan yaitu pada tahun 2018 .

3. Tingkat suku bunga yang digunakan adalah sebesar $9 \%$.

4. Pajak pendapatan tidak dimasukan kedalam perhitungan kelayakan..

5. Perubahan variabel swiching value pada analisis sensitivitas tidak diikuti dengan perubahan variabel lainnya.

\section{HASIL DAN PEMBAHASAN}

\section{Keragaan Usaha}

Masyarakat di Desa Bumi Dipasena Agung sebagian besar merupakan petambak. Bertambak merupakan sumber penghasilan utama bagi masyarakat di Desa Bumi Dipasena Agung dengan menggunakan teknologi semi intensif. Tambak dengan teknologi semi intensif menjadi pilihan bagi petambak oleh sebab dapat melakukan tebar lebih banyak dibandingkan sistem tradisional, dengan begitu bisa memanfaatkan lebih maksimal luas lahan yang dimiliki.

\section{Karakteristik Responden}

\section{Jenis Kelamin.}

Karakteristik responden berdasarkan jenis kelamin dapat dilihat pada Gambar berikut.

Gambar 1. Karakteristik Responden Berdasarkan Jenis Kelamin 


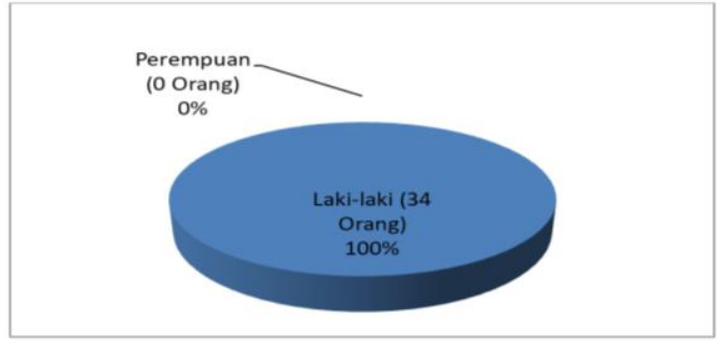

Sumber : Data Primer, 2019 (diolah)

Berdasarkan jenis kelamin yaitu sebanyak 34 Responden berjenis kelamin laki-laki.

\section{Tingkat Pendidikan.}

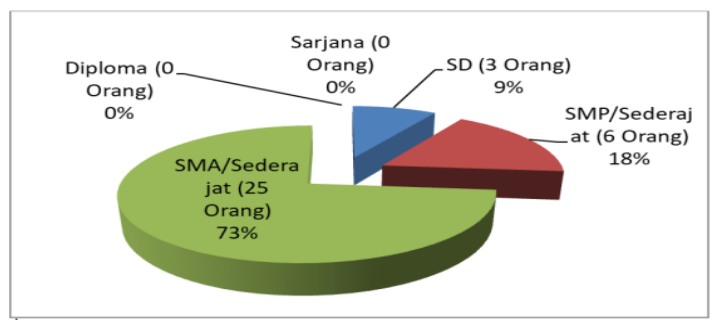

Sumber : Data Primer, 2019 (diolah)

Berdasarkan tingkat pendidikan terbesar yaitu SMA/sederajat dengan persentase sebesar $73 \%$ atau secara ratarata yaitu 11 Tahun.

Usia.

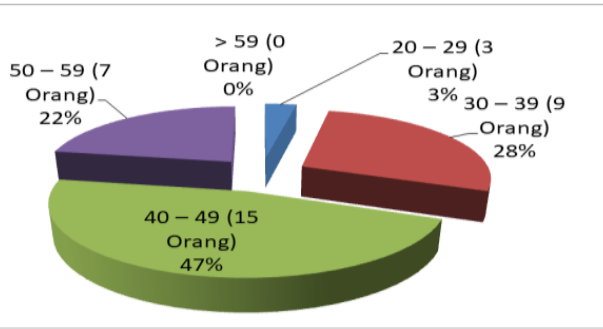

Sumber : Data Primer, 2019 (diolah)

Berdasarkan usia terbesar adalah kisaran 40-49 Tahun sebesar $47 \%$ atau secara rata-rata yaitu 43 Tahun.

\section{Pengalaman.}

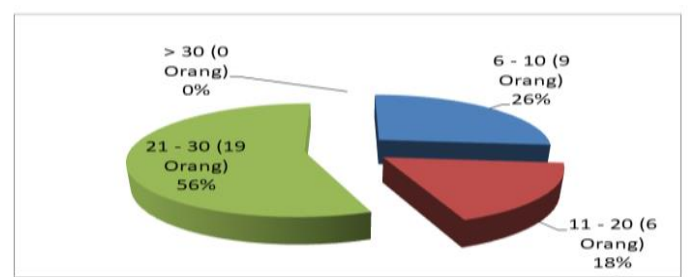

Sumber : Data Primer, 2019 (diolah)
Berdasarkan pengalaman yaitu pada kisaran 21 - 30 tahun sebesar $56 \%$ atau secara rata-rata yaitu 20 Tahun

\section{Sumber Modal Usaha}

Sumber modal usaha yang digunakan petambak dapat dilihat pada gambar berikut

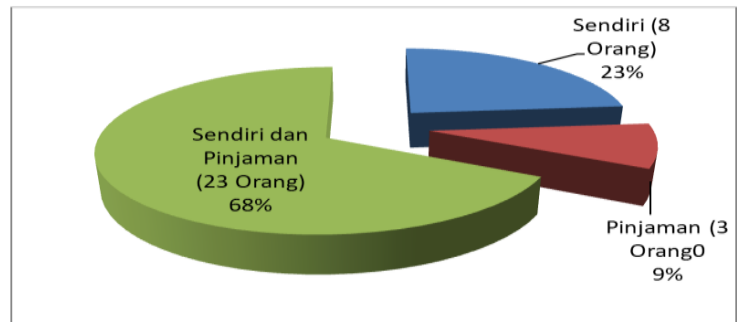

Sumber : Data Primer, 2019 (diolah)

Sumber modal usaha terbesar yang digunakan responden adalah gabungan (sendiri dan pinjaman) sebanyak 23 orang dengan persentase sebesar $68 \%$.

\section{Padat dan Usia Tebar Benur}

padat tebar terbanyak yang digunakan petambak responden yaitu 11 20 ekor $/ \mathrm{m}^{2}$ sebesar $71 \%$. Rata-rata padat tebar yang digunakan petambak responden adalah sebesar 19 ekor $/ \mathrm{m}^{2}$.

Usia tebar benur terbesar yang digunakan petambak responden yaitu post larva (PL) 10 dengan persentase sebesar $32 \%$. Rata-rata usia benur yang ditebar oleh petambak responden sebesar PL 10

\section{Lama Budidaya}

Seluruh petambak responden membudidayakan udang vaname selama 75 hari.

\section{Rantai Pemasaran}

Pemasaran yang dilakukan oleh seluruh petambak responden di tempat penelitian yaitu langsung menjual hasil panen kepada tengkulak. Dari tingkat tengkulak yaitu menjual kepada pasar modern, pasar tradisioanal dan perusahan pengekspor udang vaname daerah Jakarta, Bogor, Depok, Tangerang, dan Bekasi.

\section{Kelembagaan Petambak}

Kelembagaan yang diikuti oleh seluruh petambak responden di lokasi 
penelitian yaitu Perhimpunan Petambak Pengusaha Udang Wilayah (P3UW) Lampung.

\section{Proese Pembayaran}

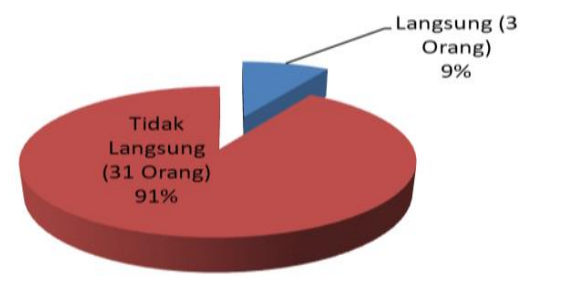

Sumber : Data Primer, 2019 (diolah)

Proses pembayaran terbesar yang digunakan oleh petambak responden adalah tidak langsung yaitu sebanyak 31 orang dengan persentase $91 \%$. Secara umum proses pembayaran tidak langsung dilakukan secara tempo yaitu $4-7$ hari pada saat petambak menjual hasil panennya

\section{Studi Kelayakan Finansial}

Untuk mengetahui kriteria-kriteria penilaian investasi tersebut terlebih dahulu mengetahui besarnya manfaat serta biaya yang dikeluarkan dalam arus kas. Perhitungan penerimaan dan biaya yaitu selama 1 tahun (3 kali budidaya atau 3 siklus produksi)

\section{Penerimaan Rata-rata}

Penerimaan rata-rata yang diperoleh petambak adalah dari hasil penjualan udang vaname. Rincian penerimaan ratarata dapat dilihat pada tabel berikut :

Tabel 1. Rincian Penerimaan Rata-rata Usaha (Luasan Tambak $4.000 \mathrm{~m}^{2}$ )

\begin{tabular}{llr}
\hline No & Siklus & $\begin{array}{c}\text { Penerimaan rata-rata } \\
(\mathrm{Rp})\end{array}$ \\
\hline 1 & I & 39.630 .000 \\
2 & II & 43.887 .000 \\
3 & III & 32.472 .000 \\
\hline & Total & 115.989 .000 \\
\hline
\end{tabular}

Sumber : Data Primer, 2019 (diolah)

Rata-rata Penerimaan total yang diterima oleh petambak yaitu sebesar
Rp.115.989.000 yang didapat selama 3 siklus produksi

\section{Nilai Sisa}

Nilai sisa dalam penelitian ini adalah dihitung berdasarkan rata-rata dari seluruh responden yaitu sebesar Rp.85.210.000

\section{Biaya Tetap Rata-rata}

Rincian biaya tetap rata-rata yang digunakan responde dapat dilihat pada tabel berikut :

Tabel 2. Rincian Biaya Tetap Rata-rata (Luasan Tambak $4.000 \mathrm{~m}^{2}$ )

\begin{tabular}{llr}
\hline No & Uraian & $\begin{array}{r}\text { Jumlah } \\
(\mathrm{Rp})\end{array}$ \\
\hline 1 & Upah Tenaga Kerja & 14.514 .000 \\
2 & Perawatan Mesin & 1.393 .500 \\
3 & Perawatan Kolam & 2.152 .500 \\
4 & Perawatan Kendaraan & 1.027 .500 \\
\hline & Total Biaya Tetap & 19.087 .500 \\
\hline
\end{tabular}

Sumber : Data Primer, 2019 (diolah)

Total biaya tetap rata-rata selama setahun yang digunakan oleh petambak yaitu sebesar Rp.44.375.100

\section{Biaya Variabel Rata-rata}

Rincian biaya variabel rata-rata yang digunakan responden dapat dilihat pada tabel berikut :

Tabel 3. Rincian Biaya Variabel Rata-rata (Luasan Tambak 4.000m²)

\begin{tabular}{llr}
\hline No & Rincian & Jumlah $(\mathrm{Rp})$ \\
\hline 1 & Benur & 9.266 .000 \\
2 & Pakan & 24.280 .500 \\
3 & Panen & 1.190 .000 \\
4 & Bahan bakar & 4.510 .000 \\
5 & Obat-obatan & 4.023 .100 \\
6 & Ikan Asin & 189.000 \\
7 & Bungkil Kedelai & 916.500 \\
\hline & Total & 44.375 .100 \\
\hline
\end{tabular}

Sumber : Data Primer, 2019 (diolah)

Total rata-rata biaya variabel ratarata selama setahun yang digunakan oleh petambak yaitu sebesar Rp.44.375.100. 


\section{Biaya Investasi Rata-rata Usaha Petambak, 2019}

Rincian investasi rugi rata-rata yang digunakan responden dapat dilihat pada tabel berikut :

Tabel 4. Rincian Biaya Investasi (Luasan Tambak $4.000 \mathrm{~m}^{2}$ )

\begin{tabular}{llr}
\hline NO & Rincian & Jumlah $(\mathrm{Rp})$ \\
\hline 1 & Lahan 5.000m & \\
2 & Kontruksi Tambak & 60.000 .000 \\
3 & Bangunan & 30.000 .000 \\
4 & Mesin & 5.411 .000 \\
5 & Peralatan & 19.659 .000 \\
6 & Kendaraan & 10.735 .000 \\
7 & Terpal Plastik & \\
& Tanggul & 24.411 .000 \\
\hline & Total & 192.715 .000
\end{tabular}

Sumber : Data Primer, 2019 (diolah)

Besarnya biaya investasi rata - rata yang dikeluarkan yaitu Rp.192.715.000.

\section{Laporan Laba Rugi Rata-rata Usaha Petambak, 2019}

Rincian biaya laba rugi rata-rata yang digunakan responden dapat dilihat pada tabel berikut :

Tabel 5. Laporan Laba Rugi (Luasan Tambak $4.000 \mathrm{~m}^{2}$ )

\begin{tabular}{llr}
\hline No & Rincian & Jumlah (Rp) \\
\hline 1 & Penerimaan & 115.989 .000 \\
2 & Total Biaya Tetap dan & \\
3 & Penyusutan & 28.920 .283 \\
4 & Total Biaya Variabel & 44.375 .100 \\
5 & Pajak & 0 \\
\hline & Pendapatan & 42.693 .617 \\
\hline
\end{tabular}

Sumber : Data Primer, 2019 (diolah)

Rata-rata pendapatan yang dihasilkan dalam usaha ini yaitu sebesar Rp.42.693.617 per tahun.

\section{Kriteria Penilaian Investasi}

Perhitungan dilakukan selama umur ekonomis proyek yaitu 7 tahun berdasarkan umur ekonomis mesin produksi. Perhitungan kelayakan finansial menggunakan tingkat suku bunga pinjaman sebesar 9\%. Hasil kriteria penilaian investasi dapat dilihat pada tabel berikut :

Tabel 6. Rincian Hasil Krieria Penilaian Investasi (Luasan Tambak $4.000 \mathrm{~m}^{2}$ )

\begin{tabular}{llc}
\hline No & Rincian & Hasil \\
\hline 1 & NPV & Rp. 131.035 .409 \\
2 & IRR & $36,5 \%$ \\
3 & PI & 1,98 \\
4 & DPP & 4 Tahun 3 Bulan
\end{tabular}

Sumber : Data Primer, 2019 (diolah)

Hasil dari perhitungan analisis finansial menunjukkan bahwa nilai NPV yaitu sebesar Rp.131.035.409. Hal ini menunjukan bahwa usaha ini layak untuk dijalankan selama tujuh tahun berjalannya usaha menunjukan NPV positif sebesar Rp.131.035.409.

Perhitungan analisis finansial menunjukkan nilai IRR yaitu sebesar $36,5 \%$. Hal ini berarti dari segi IRR usaha ini layak untuk dijalankan sebab nilai yang dihasilkan lebih besar dari bunga pinjaman yaitu $9 \%$.

Hasil dari perhitungan analisis finansial menunjukkan bahwa nilai PI yang dihasilkan yaitu sebesar 1,98 hal ini menunjukan bahwa usaha tersebut layak untuk dijalankan. Nilai PI sebesar 1,98 berarti bahwa dengan mengeluarkan biaya sebesar RP.1 maka petambak akan mendapatkan keuntungan sebesar Rp.0,98.

DPP yang dihasilkan dari perhitungan analisis finansial adalah 4 Tahun 3 Bulan, hal ini menunjukan bahwa usaha tersebut layak dengan umur ekonomis usaha selama 7 tahun dengan masa pengembalian investasi selama 4 Tahun 3 Bulan.

\section{Analisis Sensitivitas}

Analisis sensitivitas usaha petambak udang vaname semi intensif di Desa Bumi Dipasena Agung dapat dilihat pada tabel berikut :

Tabel 7. Analisis Sensitivitas (Luasan Tambak $4.000 \mathrm{~m}^{2}$ ) 


\begin{tabular}{llc}
\hline No & \multicolumn{1}{c}{ Uraian } & $\begin{array}{c}\text { Persentase } \\
(\%)\end{array}$ \\
\hline 1 & $\begin{array}{l}\text { Maksimal Penurunan } \\
\text { Jumlah Produksi }\end{array}$ & 22,37 \\
2 & $\begin{array}{l}\text { Maksimal Penurunan } \\
\text { Harga Jual }\end{array}$ & 22,37 \\
3 & $\begin{array}{l}\text { Maksimal Kenaikan } \\
\text { Harga Pakan }\end{array}$ & 107,24 \\
4 & $\begin{array}{l}\text { Maksiamal Kenaikan } \\
\text { Harga Benur }\end{array}$ & 280,99 \\
\hline
\end{tabular}

Sumber : Data Primer, 2019 (diolah)

Tabel 7 menunjukkan bahwa penurunan jumlah produksi dan penurunan harga jual merupakan parameter yang paling sensitif pada usaha petambak udang vaname semi intensif di Desa Bumi Dipasena Agung.

\section{Analisis Kelayakan Aspek Non Finansial}

Aspek non finansial dianalisis menggunakan teknik skala likert (Suliyanto, 2010). Tingkat evaluasi aspek penilaian yang digunakan yaitu :

1 = Sangat tidak layak

2 = Tidak layak

3 = Cukup tidak layak

4 = Cukup layak

5 = Layak, dan

6 = Sangat tidak layak

Data yang didapat diolah menggunakan keputusan penilaian kelayakan dihitung berdasarkan besar persentase antara jawaban 1,2,3 dan 4,5,6 dengan keterangan 1,2,3 adalah tidak layak dan 4,5,6 adalah layak. Hasil analisis aspek non finansial dapat dilihat pada tabel berikut :

Tabel 8. Analisis Aspek Kelayakan Non Finansial (Luasan Tambak $4.000 \mathrm{~m}^{2}$ )

\begin{tabular}{lcc}
\hline \multirow{2}{*}{ Aspek Penilaian } & \multicolumn{2}{c}{ Evaluasi } \\
\cline { 2 - 3 } & $\begin{array}{c}1,2,3 \\
(\%)\end{array}$ & $\begin{array}{c}4,5,6 \\
(\%)\end{array}$ \\
\hline Pasar & 2,6 & 97,4 \\
Teknis & 2 & 98 \\
Sosial Ekonomi & 0 & 100 \\
Dampak Lingkungan & 0 & 100
\end{tabular}

Sumber : Data Primer, 2019 (diolah)
Pembahasan pada aspek pasar adalah meliputi persaingan antara pengusaha udang dilokasi penelitian dan diwilayah produksi udang lainnya yaitu dinyatakan layak sebab tidak menimbulkan hal yang negatif bagi petambak. Kondisi permintaan udang ditingkat petambak juga sangat baik, dari pengalaman petambak selama mandiri udang yang diproduksi sepenuhnya terjual, begitu juga dari penawaran juga kondisinya baik, dari tingkat penyedia input dan tengkulak jumlahnya banyak begitu pula timbal baliknya bagi petambak sebab penyedia input saling beradu program dan keunggulan atas produk yang ditawarkan. Kondisi harga jual di lokasi penelitian yaitu baik.

Pembahasan pada aspek teknis adalah meliputi kondisi lokasi tambak yaitu layak dengan kontruksi sesuai dengan fungsinya baik itu kanan inlet, outlet, dan juga tambak semua tertata dengan baik oleh sebab tidak banyak berubah dari pada masa inti plasma. Ketersedian mesin, peralatan, dan suku cadangnya yaitu tercukupi dan mendapatkannya juga cukup mudah di lokasi penelitian, begitu pula dengan ketersedian pakan, benur, dan obat-obatan semua mudah didapatkan di lokasi penelitian. Ketersedian sumberdaya manusia yaitu mencukupi, tidak hanya petambak namun peran pemerintah desa dan juga lembaga seperti P3UW Lampung juga tercukupi dan sangat membantu dalam menunjang keberlang sungan usaha.

Kelayakan aspek sosial dinyatakan layak dengan persentase sebesar $100 \%$. Pembahasan aspek sosial yaitu meliputi kondisi kemasyarakatan yang baik salah satunya adalah dengan adanya P3UW sebagai wada inspirasi bagi petambak, namun pada kenyataannya masih ada beberapa petambak yang melanggar peraturan yang berlaku. Selain itu tersediannya sarana prasarana seperti jembatan dan jalan yang dapat dipakai oleh petambak dan masyarakat sekitar. 
Kelayakan aspek ekonomi dinyatakan layak dengan persentase sebesar $100 \%$. Pembahasan aspek ekonomi yaitu meliputi meningkatnya pendapatan keluarga dari pada usaha tambak yang dilakukan. Membuka lapangan perkerjaan baik itu sebagai pelaku usaha atau pun masyarakat sekitar seperti industri atau penjual pakan, benur, obat-obatan, peralatan, ikan asin, dan bungkil kedelai.

Kelayakan aspek dampak lingkungan dinyatakan layak dengan persentase sebesara 100\%.Tidak ada dampak negatif yang ditimbulkan dari usaha ini baik terhadap darat, air, dan udara, oleh sebab tidak dipakainya bahan yang berbahaya bagi lingkungan, selain itu untuk mencegah terjadinya abrasi para petambak kembali menanami hutan bakau di bibir-bibir pantai.

\section{KESIMPULAN DAN IMPLIKASI KEBIJAKAN}

\section{Kesimpulan}

Dari hasil penelitian usaha petambak udang vaname semi intensif di Desa Bumi Dipasena Agung dapat disimpulkan bahwa

1. Keragaan usaha petambak udang vaname semi intensif di Desa Bumi Dipasena Agung yaitu : Sumber modal terbesar yang digunakan adalah sendiri dan pinjaman dengan persentase sebesar $68 \%$, padat tebar terbesar yaitu $11-20$ ekor/m2 dengan persentase sebesar $71 \%$ atau rata-rata yaitu 19 ekor/m2, usia tebar benur yaitu terbesar adalah post larva (PL) 10 dengan persentase sebesar 32\% atau rata-rata yaitu PL 10, Lama pembudidayaan yaitu selama 75 hari, rantai pemasaran yaitu dari petembak kepada tengkulak, kelembagaan petambak yang diikuti adalah Perhimpunan Petambak Pengusaha Udang Wilayah (P3UW) Lampung, penentuan harga adalah ditentukan oleh tengkulak, proses pembayaran terbesar adalah tidak langsung dengan persentase sebesar $91 \%$.
2. Usaha petambak udang vaname semi intensif di Desa Bumi Dipasena Agung adalah layak dengan hasil kriteria penilaian investasi meliputi NPV sebesar Rp.131.035.409 yang berarti layak yaitu lebih dari 0, IRR sebesar 36,5\% yang berarti lebih besar dari bunga pinjaman yaitu 9\%, PI sebesar 1,98 yang berarti setiap Rp.1 biaya yang dikeluarkan maka akan diperoleh keuntungan sebesar Rp.0,98, dan DPP selama 4 Tahun 3 Bulan yaitu layak sebab lebih kecil dari umur ekonomis usaha yaitu 7 Tahun

3. Analisis sensitivitas usaha petambak udang vaname semi intensif di Desa Bumi Dipasena Agung menunjukkan bahwa maksimum penurunan jumlah produksi dan harga jual sebesar $22,37 \%$ serta maksimum kenaikan harga pakan sebesar 107,24\%, dan benur sebesar $280,99 \%$.

\section{Implikasi Kebijakan}

Beberapa implikasi kebijakan yang dapat disampaikan dalam usaha petambak udang vaname semi intensif di Desa Bumi Dipasena Agung adalah sebagai berikut :

1. Petambak untuk lebih memperhatikan dan menaati peraturan yang berlaku di Desa Bumi Dipasena Agung supaya dapat meminimalisir terjadinya serangan penyakit pada udang vaname serta memperlancar kegiatan usaha dengan mengedepankan kepentingan bersama.

2. Bagi pemerintah agar lebih memperhatikan para petambak udang vaname di Desa Bumi Dipasena Agung sebab tidak adanya tenaga penyuluh. Tenaga penyuluh sangat dibutuhkan oleh sebab para petambak banyak menghadapi masalah dalam melakukan usahanya salah satunya adalah sulitnya menangani serangan penyakit pada udang vaname yang dibudidayakan, dan

3. Hasil analisis sensitivitas menunjukkan bahwa petambak harus memperhatikan tingkat kenaikan atau 
penurunan maksimum komponen biaya dan penerimaan yang dapat menjadi titik impas keuntungan yang diperoleh, yaitu penurunan jumlah produksi dan harga jual sebesar $22,37 \%$ serta kenaikan harga pakan sebesar 107,24\%, dan benur sebesar $280,99 \%$.

\section{Daftar Pustaka}

Amri, K dan Kanna, I. 2008. Budi Daya Udang Vaname Secara Intensif, Semi Intensif, dan Tradisional. PT Gramedia Pustaka Utama. Jakarta.

Badan Pusat Statistik Kabupaten Tulang Bawang. 2017. Kecamatan Rawajitu Timur Dalam Angka. https://tulangbawangkab.bps.go.id. Diakses pada 15 Agustus 2018

Bank Indonesia. 2015. Kajian Ekonomi dan Keuangan Regional Provinsi Lampung Triwulan II tahun 2015. Kantor Perwakilan Bank Indonesia Provinsi Lampung. www.bi.go.id. Diakses pada 6 Agustus 2018

Direktorat Jenderal Perikanan Budidaya. 2013. 10 Provinsi Produsen Utama Udang Vaname 2013. Kementerian Kelautan dan Perikanan. www.djpb.kkp.go.id. Diakses pada 20 Juli 2018

Gittinger, J Price. 2008. Analisa Ekonomi Proyek-proyek Pertanian. [Edisi Kedua]. Penerjemah Slamet Utomo dan Komet Mangiri. Universitas Indonesia. Jakarta

Kasmir dan Jakfar. 2017. Studi Kelayakan Bisnis [Edisi Revisi]. Prenadamedia group. Jakarta

Khrisna, W. Warsika, I. Dan Frederika, A. 2013. Analisis Capital Recovery Investasi Pada Proyek Condotel The Jimbaran View. Jurnal Ilmiah Elektronik Infrastruktur Teknik Sipil, Vol. 2 No. 1. Universitas Udayana, Denpasar

Peta Administrasi Kecamatan Rawajitu Timur. 2015. Kab Tulang Bawang. www. Tulangbawangkab .go.id. Di \begin{tabular}{llll}
\hline akses pada 1 & Mei & &
\end{tabular} 


\section{LAMPIRAN}

Lampiran 1. Produksi Komoditas Udang di Indonesia

\begin{tabular}{|c|c|c|c|c|c|c|}
\hline \multirow[t]{2}{*}{ Komoditas } & \multicolumn{5}{|c|}{ Tahun/Year } & \multirow{2}{*}{$\begin{array}{l}\begin{array}{l}\text { Kenaikan } \\
\text { rata-rata \% }\end{array} \\
2010-2014\end{array}$} \\
\hline & 2010 & 2011 & 2012 & 2013 & 2014 & \\
\hline $\begin{array}{l}\text { Volume Produksi } \\
\text { (ton) }\end{array}$ & 380,972 & 401,154 & 415,703 & 638,955 & 592,219 & 13.83 \\
\hline $\begin{array}{l}\text { Udang Windu } \\
\text { (ton) }\end{array}$ & 125,519 & 126,157 & 117,888 & 171,583 & 126,595 & 3.32 \\
\hline $\begin{array}{l}\text { Udang Vaname } \\
\text { (ton) }\end{array}$ & 206,578 & 246,420 & 251,763 & 390,278 & 411,729 & 20.49 \\
\hline $\begin{array}{l}\text { Udang lainnya } \\
\text { (ton) }\end{array}$ & 48,875 & 28,577 & 46,052 & 77,094 & 53,895 & 14,23 \\
\hline $\begin{array}{l}\text { Volume ekspor } \\
\text { Udang (ton) }\end{array}$ & 145,092 & 158,062 & 162,068 & 162,410 & 141,042 & $-0,37$ \\
\hline
\end{tabular}

Sumber : Direktorat Jenderal Perikanan Budidaya, 2015

Lampiran 2. Peta Administrasi Kecamatan Rawajitu Timur tahun 2015

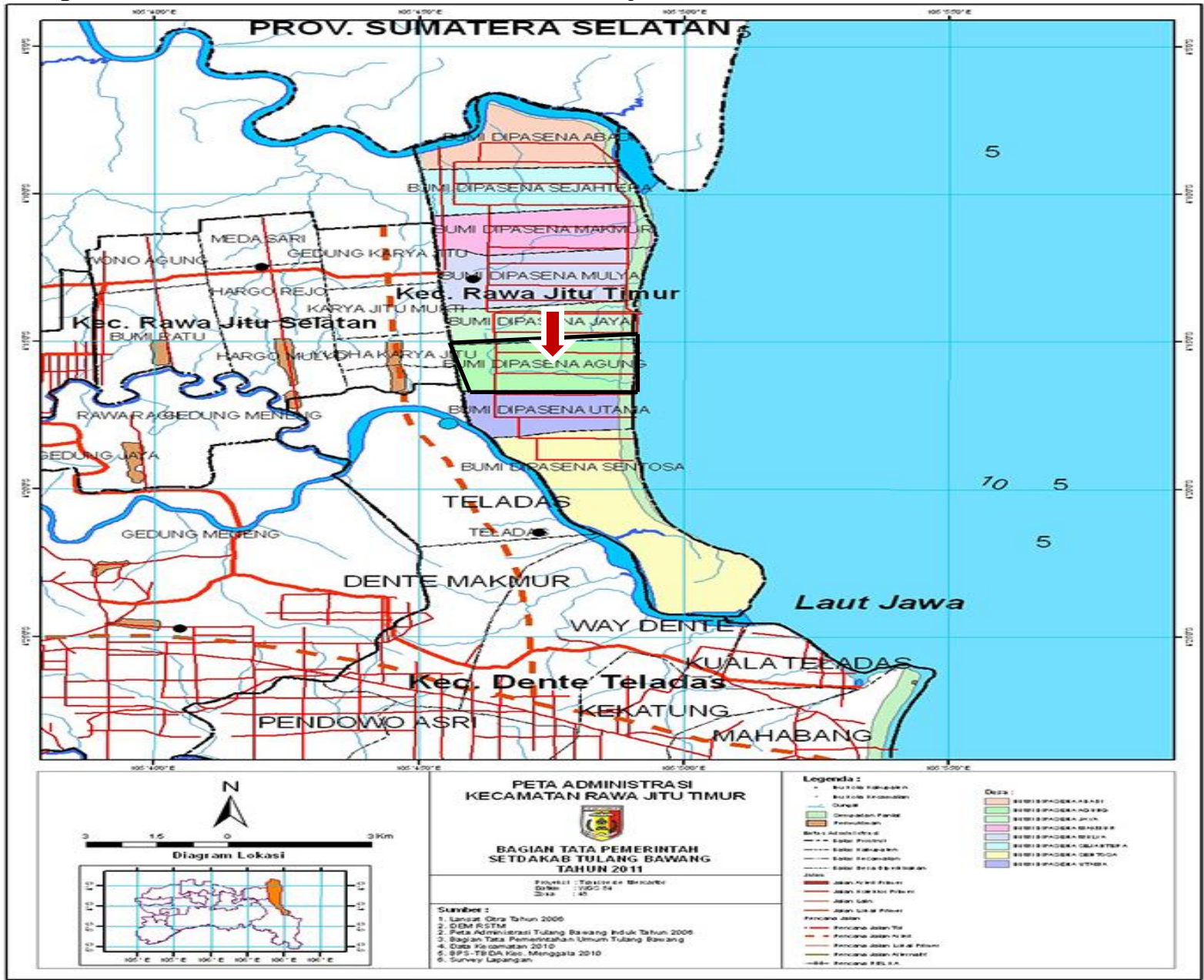

Sumber : www.tulangbawangkab.go.id (Di akses pada 1 Mei 2019) 
Tabel 3. Kriteria Budidaya Udang Vaname Dengan Teknologi Intensif, Semi Intensif, dan Ekstensif

\begin{tabular}{|c|c|c|c|}
\hline \multirow[b]{2}{*}{ Parameter } & \multicolumn{3}{|c|}{ Spesifikasi teknologi } \\
\hline & Intensif & Semi intensif & Ekstensif \\
\hline Luas petak (ha) & $<0,5$ & $>0,5-1,0$ & $>1,0$ \\
\hline Bentuk petakan & $\begin{array}{l}\text { Bujur sangkar/ } \\
\text { lingkaran/persegi } \\
\text { panjang }\end{array}$ & $\begin{array}{l}\text { Bujur sangkar/ } \\
\text { persegi panjang }\end{array}$ & $\begin{array}{l}\text { Tidak ada } \\
\text { Persyaratan }\end{array}$ \\
\hline Caren & $\begin{array}{l}\text { Saluran pembuangan } \\
\text { tengah (central } \\
\text { drain) }\end{array}$ & $\begin{array}{l}\text { Saluran pembuangan } \\
\text { tengah (central } \\
\text { drain) }\end{array}$ & Saluran/parit keliling \\
\hline $\begin{array}{l}\text { Pematang } \\
\text { Bahan } \\
\text { Lereng }\end{array}$ & $\begin{array}{l}\text { Tanah/beton } \\
1:(1-1,5)\end{array}$ & Tanah $1:(1-1,5)$ & Tanah $1:(1-1,5)$ \\
\hline Pintu air & $\begin{array}{l}2 \text { (terpisah, pintu } \\
\text { buang di tengah) }\end{array}$ & $\begin{array}{l}2 \text { (terpisah, pintu } \\
\text { buang di tengah) }\end{array}$ & 1 atau 2 \\
\hline $\begin{array}{l}\text { Kedalaman } \\
\text { air }(\mathrm{cm})\end{array}$ & $100-120$ & $100-120$ & $60-80$ \\
\hline Sistem irigasi & Close system & Semi close system & Open system \\
\hline Aerator & $\begin{array}{l}1 \mathrm{PK} / 600 \mathrm{~kg} \\
\text { Udang }\end{array}$ & $\begin{array}{l}1 \mathrm{PK} / 600 \mathrm{~kg} \\
\text { Udang }\end{array}$ & - \\
\hline $\begin{array}{l}\text { Pompa air } \\
\text { Padat tebar } \\
\left(\text { ekor } / \mathrm{m}^{2}\right)\end{array}$ & $\begin{array}{l}\text { Mutlak } \\
100-125\end{array}$ & $\begin{array}{l}\text { Mutlak } \\
25-50\end{array}$ & $\begin{array}{l}\text { Tersedia } \\
5-10\end{array}$ \\
\hline Pakan & Pakan buatan & $\begin{array}{l}\text { Pakan buatan dan } \\
\text { Alami }\end{array}$ & Pakan alami \\
\hline SR $(\%)$ & 80 & 80 & 80 \\
\hline $\begin{array}{l}\text { Produksi } \\
\text { (kg/ha/MT) }\end{array}$ & $>8.000$ & $2.400-4.000$ & $800-1600$ \\
\hline Tandon & Mutlak & Sebaiknya ada & \\
\hline
\end{tabular}

Sumber : Amri dan Kanna, 2008 
Lampiran 4. Cashflow Rata-rata Usaha Petambak Udang Vaname Semi Intensif di Desa Bumi Dipasena Agung Dengan Jumlah Responden 34 Orang Pada Luasan Tambak $4.000 \mathrm{~m}^{2}$, Tahun 2019

\begin{tabular}{|c|c|c|c|c|c|c|c|c|}
\hline & Uraian & \multicolumn{7}{|c|}{ Tahun } \\
\hline & Penerimaan & 115.989 .000 & 115.989 .000 & 115.989 .000 & 115.989 .000 & 115.989 .000 & 115.989 .000 & 115.989 .000 \\
\hline & Total Inflow & 115.989 .000 & 115.989 .000 & 115.989 .000 & 115.989 .000 & 115.989 .000 & 115.989 .000 & 201.199 .000 \\
\hline B & Outflow & & & & & & & \\
\hline 1 & Biaya Investasi & & & & & & & \\
\hline & Lahan & 60.000 .000 & & & & & & \\
\hline & Rumah tambak & 31.847 .000 & & & & & & \\
\hline & Rumah mesin diesel & 652.000 & & & & & & \\
\hline & Mesin diesel & 4.235 .000 & & & & & & \\
\hline & Kincir air & 2.823 .000 & & & & & & \\
\hline & Pompa air & 1.176 .000 & & & & & & \\
\hline & Perangkat tenaga surya & 5.044 .000 & & & & & & \\
\hline & Sepeda motor & 10.735 .000 & & & & & & \\
\hline & Terpal plastik Tanggul & 24.411 .000 & & & & & & \\
\hline & Ancho & 329.000 & 329.000 & 329.000 & 329.000 & 329.000 & 329.000 & 329.000 \\
\hline & Jembatan ancho & 670.000 & & & & & 670 & \\
\hline & Jaring jala & 947.000 & & & 947.000 & & & 947.000 \\
\hline & Timbangan & 626.500 & & & & & & \\
\hline & Cangkul & 78.000 & & 78.000 & & 78.000 & & 78.000 \\
\hline & Ember & 23.000 & 23.000 & 23.000 & 23.000 & 23.000 & 23.000 & 23.000 \\
\hline & Gayung pakan & 32.000 & 32.000 & 32.000 & 32.000 & 32.000 & 32.000 & 32.000 \\
\hline
\end{tabular}


Lampiran 4. Lanjutan

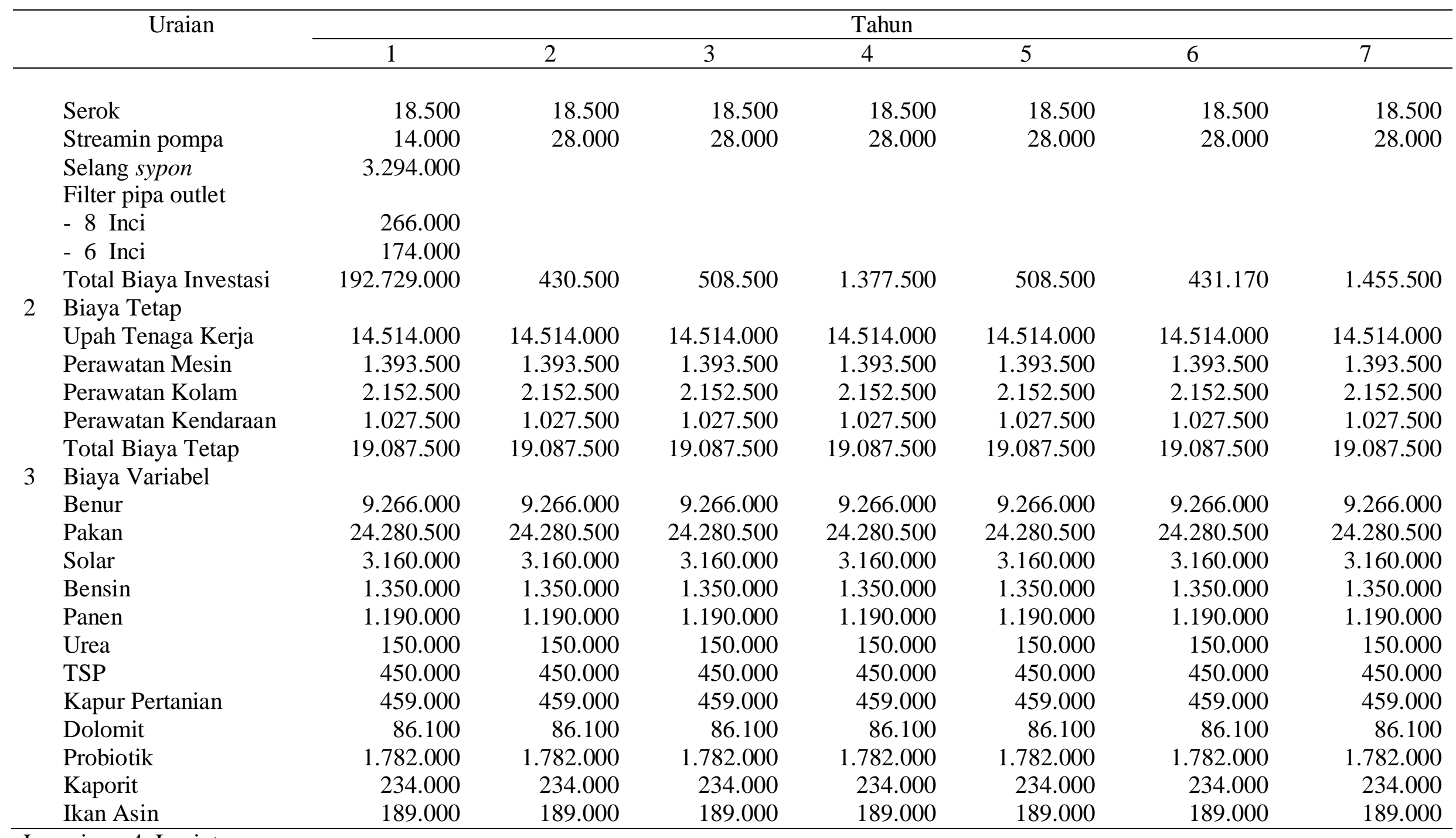

Lampiran 4. Lanjutan 


\begin{tabular}{|c|c|c|c|c|c|c|c|}
\hline \multirow[t]{2}{*}{ Uraian } & \multicolumn{7}{|c|}{ Tahun } \\
\hline & 1 & 2 & 3 & 4 & 5 & 6 & 7 \\
\hline Lodan & 195.000 & 195.000 & 195.000 & 195.000 & 195.000 & 195.000 & 195.000 \\
\hline Saponin & 570.000 & 570.000 & 570.000 & 570.000 & 570.000 & 570.000 & 570.000 \\
\hline Total Biaya Variabel & 44.375 .100 & 44.375 .100 & 44.375 .100 & 44.375 .100 & 44.375 .100 & 44.375 .100 & 44.375 .100 \\
\hline Total Outflow & 256.191 .600 & 63.893 .100 & 63.971 .100 & 64.840 .100 & 63.971 .100 & 63.893 .770 & 64.918 .100 \\
\hline PV/Tahun & -128.621 .865 & 43.843 .909 & 40.168 .222 & 36.233 .881 & 33.806 .433 & 31.059 .176 & 74.545 .652 \\
\hline PV Positif & 259.657 .274 & & & & & & \\
\hline PV Negatif & -128.621 .865 & & & & & & \\
\hline NPV & 131.035 .409 & & & & & & \\
\hline IRR $(\%)$ & 36,5 & & & & & & \\
\hline PI & 1,98 & & & & & & \\
\hline
\end{tabular}

Sumber : Data Primer, 2019 (diolah) 